\title{
Engineering-geological and geotechnical investigations for risk assessment of the University Olympic Village in Izmir (Turkey)
}

\author{
Cem Kincal ${ }^{1, *}$, Mehmet Yalçın Koca ${ }^{1}$, H. Recep Yılmaz ${ }^{2}$, Mustafa Akgün ${ }^{3}$, \\ Şenol Özyalın³, Tuğba Eskişar², Zafer Akçı̆̆ ${ }^{3}$, A.J. (Tom) van Loon ${ }^{4}$
}

\footnotetext{
${ }^{1}$ Geological Engineering Department, Engineering Faculty, Dokuz Eylul University, 35160, Tinaztepe Campus, BucaIzmir, Turkey; e-mail: cemkincal@gmail.com

${ }^{2}$ Civil Engineering Department, Engineering Faculty, Ege University, 35100, Bornova-Izmir, Turkey

${ }^{3}$ Geophysical Engineering Department, Engineering Faculty, Dokuz Eylul University, 35160, Tinaztepe Campus, Buca-Izmir, Turkey

${ }^{4}$ Institute of Geology, Adam Mickiewicz University, Maków Polnych 16, 61-606, Poznań, Poland; e-mail: tvanloon@amu.edu.pl

* corresponding author
}

\begin{abstract}
The Metropolitan Municipality of Izmir (Turkey) designated a steeply inclined area for the construction of buildings to house the participants of the Izmir University Olympic Games. Before the construction activities could start, engineering geological and geotechnical investigations had to be carried out in order to establish which zones in the area were suitable for safe constructions. Seismic studies, borings and laboratory tests yielded the data, which were used for preparing five hazard maps in a GIS environment. The construction activities based on the results of this complex investigation appeared successful. The engineering geological investigations included geotechnical measurements on core samples obtained from the boreholes (core drilling) and laboratory testing. The rock-quality designation (RQD\%) values of the rock units were determined and used in the rock-mass classification (rock-mass rating method) as an input parameter and in the calculation of the bearing capacity of the various rock units. Geophysical surveys were carried out to determine the seismic velocity of the rocks at the site. A short overview is provided of the main problems that had to be dealt with, and of the successive steps taken to solve the engineering-geological problems. Determination of these problems is necessary for adequate land-use planning and construction activities.
\end{abstract}

Keywords: engineering geology, hazard maps, bearing capacity, Izmir, Turkey

\section{Introduction}

Athletes participating in the Universiade Olympic Games in Izmir (Turkey) were to be housed in a newly to built Olympic Village with buildings of 2, 4 and 8 floors. A steeply inclined site of $0.5288 \mathrm{~km}^{2}$ was reserved by the Izmir Metropolitan Municipality for the purpose 

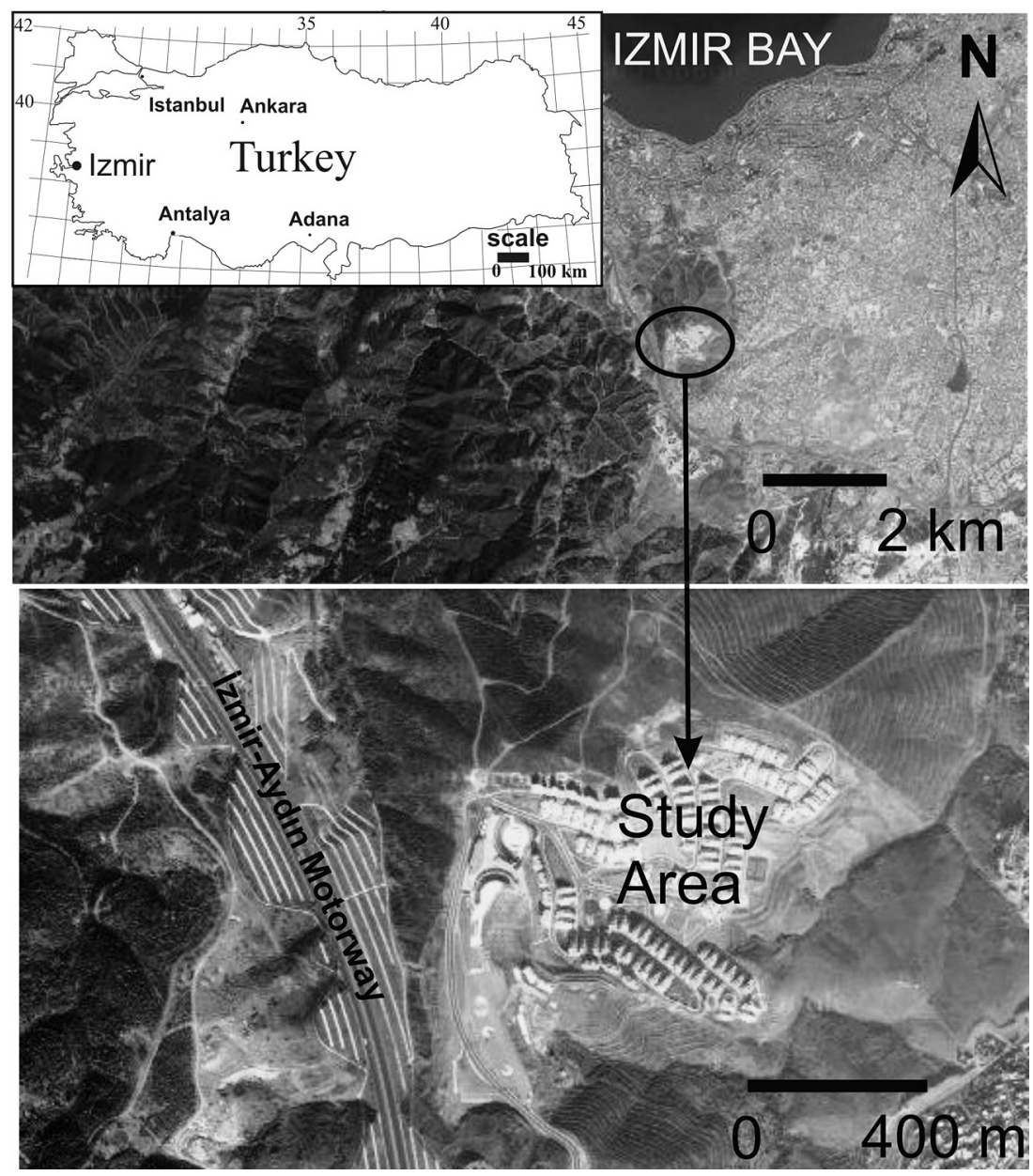

Fig. 1. Location map of the study area (modified from Web_1).

at the southern rim of Izmir Bay (Fig. 1). This terrain was, obviously, not immediately suitable for construction activities. Artificial terraces had first to be constructed as basements. This required suitable ground conditions, and it had to be investigated whether the area was geotechnically suitable and/or whether specific parts were more suitable than others.

Geological, geophysical and geotechnical studies were therefore carried out. They formed the basis of a land-suitability map that was prepared with the help of Geographical Information Systems (GIS). The land-suitability map was to be prepared in unprecedented detail (1:1000), so that it would be possible to subdivide the relatively small envisaged construction areas in zones that posed acceptable, less acceptable and unacceptable risks (Kincal et al., 2009). The present contribution focuses on the engineering-geological and geotechnical investigations, such as those regarding the bearing capacity of the rocks and a rock-mass classification for risk assessment of the construction site.

\section{Geological setting}

The area is constituted mainly by the Late Cretaceous-Paleocene Bornova Flysch Formation that consists of sandstone/shale intercalations developed in a flysch facies (Tarcan \& Koca, 2001; Koca \& Kincal, 2004; Kincal \& Koca, 2009; Kincal et al., 2009). Where the sandstones outcrop, the slopes are steep; the shale outcrops are less inclined (10-20 $)$. Some volcanic rocks - mainly andesite - are also exposed in the area (Figs. 2 and 3); the eastern part of the andesitic area is covered with slope sediments that are 1.5-7.0 $\mathrm{m}$ thick.

The boundaries between the sandstones and shales vary in depth, even within a few metres. Both the sandstones and the shales have joint sets, mainly two sets that have N10-30W and 
Fig. 2. Geological and borehole location map of the study area.

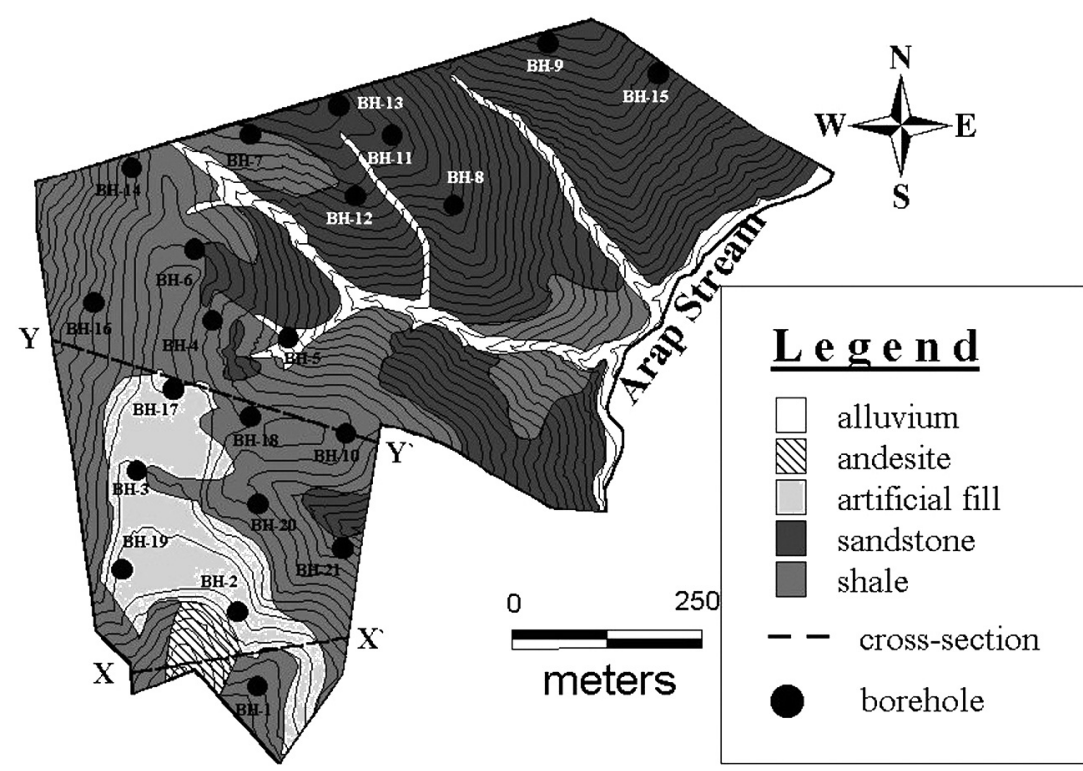

Quaternary

g. 3. Stratigraphic columnar section of the study area. 
N50-80E directions, respectively. The strikes of these two sets are almost perpendicular to one another. The joint planes generally dip over $45^{\circ}$. The andesites show also two joint sets, mainly with N70-80E/65NW and N20-30E/55NW directions.

\section{Mineralogical and geochemical studies}

The minerals in the graphitic shales have first been identified by thin-section analysis. Because the particles of the shales are dominantly clay- and silt-sized, it was difficult to identify all minerals by this method, so X-ray analysis has also been used to determine the composition of the shales. Minerals that were identified by $\mathrm{X}$-ray analysis were found to be quartz, plagioclase, calcite, chlorite, illite, and possibly smectite (non-expanding clay minerals) (Fig. 4).

\section{Methods}

Most of the data in this study have an engineering-geological character. Initially 1:1.000scale engineering-geological, groundwater-table and slope-zoning maps - consisting of four sheets - were prepared. Then, five geophysical maps were prepared by conducting seismic studies: (a) a distribution map of the S-wave velocity $\left(\mathrm{V}_{\mathrm{s}}\right)$, (b) a distribution map of Poisson's ratio $(v)$

$$
v=\frac{0.5 \times\left(\frac{V_{p}}{V_{s}}\right)^{2}}{\left(\frac{V_{p}}{V_{s}}\right)^{2}-1}
$$

(Bowles, 1988), (c) a distribution map of the site amplification (A), (d) a distribution map of the maximum ground acceleration $\left(\mathrm{a}_{\max }\right)$, and (e) a distribution map of the natural period $\left(\mathrm{T}_{0}\right)$ (Kincal et al., 2009). Each map forms a layer in the GIS process. These maps were digitised and obtained data were integrated into hazard maps. The geotechnical investigations that were carried out for the purpose are detailed in section 5 .

Bearing-capacity studies were carried out at the proposed construction site of the Olympic village consisting of shales, sandstones and andesites. To estimate the bearing capacity of the rock units, two empirical equations suggested by Hoek et al. (2002) and Serrano \& Olalla (1994), respectively, were used. The method suggested by Serrano \& Olalla (1994) was based on the Hoek-Brown empirical failure criterion. However, the use of the so-called

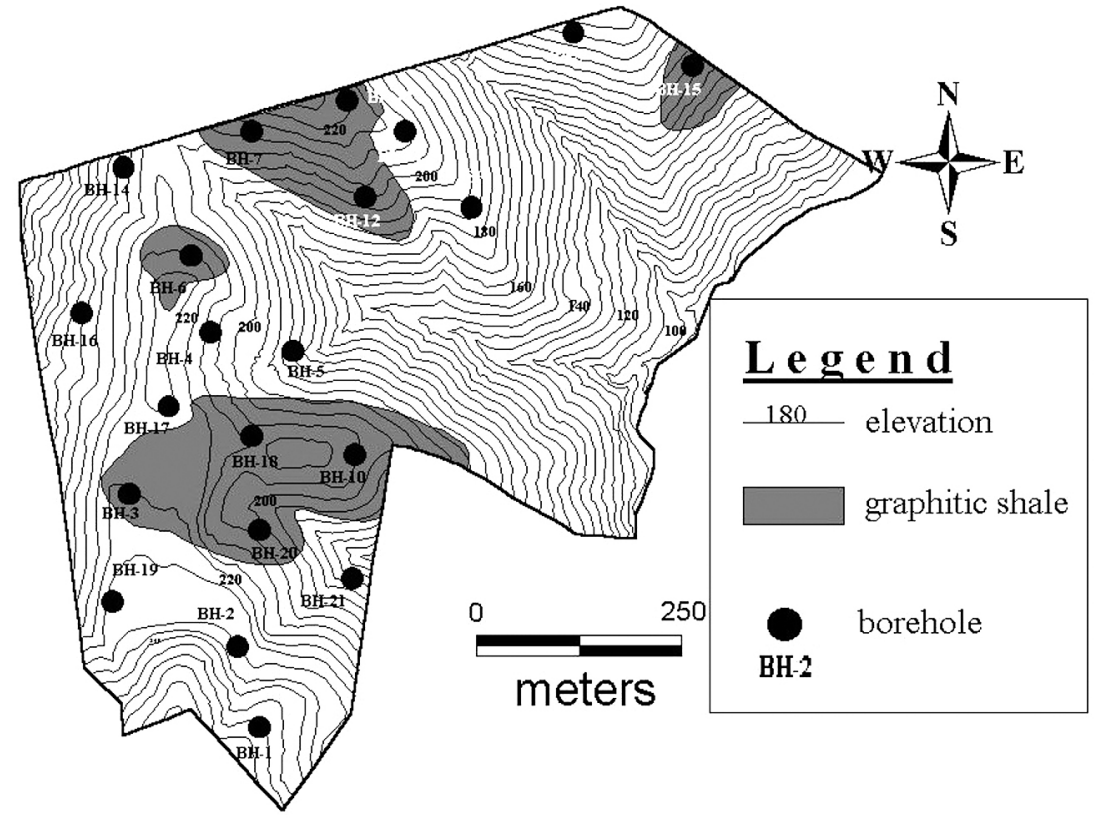

Fig. 4. Graphitic shale distribution map of the study area. 


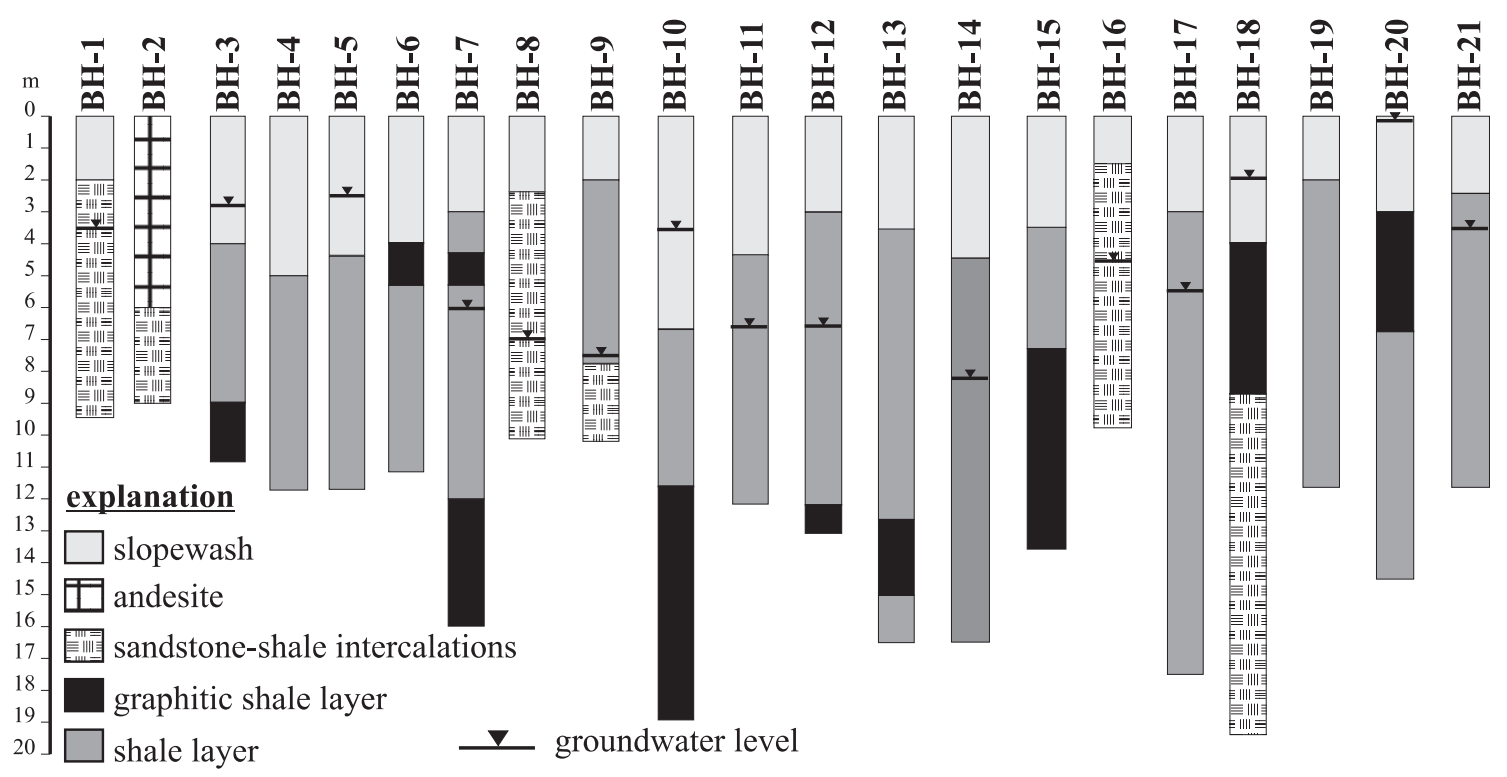

Fig. 5. Lithology in the upper part of the 21 boreholes (see Fig. 2 for locations).

Geological Strength Index (GSI) in the equations suggested by Serrano \& Olalla (1994) and Merifield et al. (2006) results in overestimation of the bearing capacity. The GSI, introduced by Hoek (1994), provides a system for estimating the reduction in rock-mass strength for various geological conditions. GSI charts have been prepared on this basis by several researchers (a.o. Hoek, 1994; Sönmez \& Ulusay, 1999; 2002; Marinos \& Hoek, 2001; Hoek et al., 2005). The chart suggested by Marinos \& Hoek (2001) was used in the bearing-capacity analyses in order to estimate the GSI values for the various geological units.

Some researches suggest that the HoekBrown failure criterion should not be used if the rock mass consists of a strong blocky rock such as sandstone, separated by clay-coated and slicken-sided bedding surfaces. As a result of the anisotropic and heterogeneous nature of the laminated rock-mass structure category, Marinos \& Hoek (2001) also proposed a special GSI chart only for the classification of heterogeneous rock masses such as flysch. The GSI chart was used to estimate the value of the GSI from the field observations of blockiness and discontinuity surface conditions.

\section{Engineering-geological investigations}

The various engineering-geological investigations needed to provide the data for the maps that are described in Section 3. They included (a) determination of rock strength and stability; and (b) geophysical aspects, including determination of (1) the seismic velocity of the rocks, (2) the Poisson's ratio, (3) the site-amplification values, (4) the ground acceleration of the top layer, and (5) the natural period of the top layer.

\section{Determination of rock strength and stability}

Rock strength and stability were determined by both analysis of borehole data (Figs. 4 and 5), derived from 21 locations, and in-situ tests. The data thus obtained were used as input for the bearing-capacity calculations. The susceptibility to mass movements was determined by an inventory of zones with steep slopes (a $\geq 36 \%$ ). An assessment of the suitability for construction was further obtained by carrying out various laboratory tests to determine the physical and mechanical properties of the 
Table 1. Mean laboratory test results for the samples of weathered shales and sandstones.

\begin{tabular}{lcc}
\hline \multicolumn{1}{c}{ Test type } & $\begin{array}{c}\text { Sandstone } \\
\text { samples }\end{array}$ & Shale samples \\
\hline $\begin{array}{l}\text { dry unit weight } \\
{\left[\mathrm{kN} / \mathrm{m}^{3}\right]}\end{array}$ & $25.40 \pm 0.58$ & $25.20 \pm 0.55$ \\
saturated unit weight & $27.15 \pm 0.50$ & $25.76 \pm 0.44$ \\
{$\left[\mathrm{kN} / \mathrm{m}^{3}\right]$} & $1.74 \pm 0.96$ & $5.65 \pm 2.20$ \\
porosity [\%] & $0.70 \pm 0.48$ & - \\
$\begin{array}{l}\text { water content }[\omega \%] \\
\text { point load strength } \mathrm{Is}_{50}\end{array}$ & $4.56 \pm 0.53$ & - \\
$\begin{array}{l}\mathrm{MPa}] \\
\text { uniaxial compressive }\end{array}$ & $70.5 \pm 2.36$ & $20.2 \pm 4.8$ \\
$\begin{array}{l}\text { strength }[\mathrm{MPa}] \\
\text { internal friction angle } \\
(\varphi)\left[{ }^{\circ}\right]\end{array}$ & 42 & 26 \\
cohesion $(\mathrm{c})[\mathrm{MPa}]$ & 14.2 & 1.35 \\
\hline
\end{tabular}

shale, sandstone (Tab. 1) and andesite samples collected from the 21 boreholes and from excavations in the study area.

The uniaxial compressive strength (UCS) and the direct shear strength (DSS) of the sandstones, shales and andesites were determined according to ISRM (1981). Additionally, the physical properties of the rocks exposed in the field were investigated by various laboratory tests. The samples were prepared and tested in accordance with the procedures prescribed by ISRM (1981). UCS tests and point-load (PL) tests were performed to determine the strength of the rocks.

The results of the UCS tests of the rocks, in particular those exposed, were used for a bearing-capacity analysis and for rock-mass classification. The allowable bearing capacities of sandstone, andesite and shale were calculated using two methods: the rock-mass rating (RMR) method (Serrano \& Olalla, 1994) and the geological-strength index (GSI) method (Hoek \& Bray, 1997). Additionally, rock-on-rock DSS tests were performed on discontinuities in sandstone and shale samples to determine the shear-strength parameters according to the procedure recommended by Brown (1981).

The general theory of the ultimate bearing capacity is applied to the specific case of assuming that the modified Hoek-Brown criterion applies. The methodology followed is identical to the one used by Serrano \& Olalla (1994):

$$
P_{h}=\beta_{n}\left(N_{\beta}-\zeta_{n}\right)
$$

where $P_{h}$ is the ultimate bearing capacity, and values of factor $\mathrm{N}_{\beta}$ for different values of the exponent $\mathrm{n}$ - with horizontal ground and vertical external loads are calculated as

$$
\mathrm{N}_{\beta}=\left(\frac{1-\sin \rho_{1}}{k \sin \rho_{1}}\right)^{1 / k} \times[n] \times\left[\frac{1+\sin \rho_{1}}{\sin \rho_{1}}\right]+1
$$

where $\rho_{1}$ is the instantaneous friction angle. This is the angle that the tangent to the MohrCoulomb envelope forms with the abscissa axis, at the tangent point to Mohr's circle.

Since $\mathrm{n}=0.65-(\mathrm{GSI} / 200), \mathrm{k}=(1-\mathrm{n}) / \mathrm{n}$, $\zeta=\mathrm{s} / \mathrm{m} \mathrm{A}_{\mathrm{n}}$ (s and $\mathrm{m}$ are Hoek-Brown constants), $A n=m(1-n) / 2^{1 / n}$ and $\beta_{n}=A_{n} \times \sigma_{c}$ where $\sigma_{c}$ is the UCS value of the rock.

\section{Geophysical investigations}

Several types of geophysical survey have been carried out to determine the seismic velocity of the rocks at the envisaged construction site. Apart from the seismic velocities $\left(\mathrm{V}_{\mathrm{p}^{\prime}}\right.$ $\mathrm{V}_{\mathrm{S}}$ ), the thicknesses $(\mathrm{H})$ and the unit weights $\left(\gamma_{n}\right)$ of the rock units that are located at different depths have been determined. The most relevant investigations are detailed in the underneath subsections.

In order to study the seismic velocity, 34 $\mathrm{P}$ - and S-wave surveys were carried out with a series of geophones at $2 \mathrm{~m}$ spacing. A vertical profile to a depth of $20 \mathrm{~m}$ was thus investigated. It was found that the velocity was particularly high in the one but highest rock unit, where it ranges from 800 to $1900 \mathrm{~m} / \mathrm{s}$. Only the topmost rock unit was mapped, however, because the lower rock units are certainly safe with regard to building. For the topmost unit, safety is considered to be guaranteed where $V_{s}$ is higher than $450 \mathrm{~m} / \mathrm{s}$ (Kincal et al., 2009).

The site-amplification distribution has been calculated according to the formula presented by Midorikawa (1987): $\mathrm{A}=68^{*} \mathrm{~V}_{\mathrm{S}}^{-0.6}$. Using the site-amplification and the ground-acceleration data of the main rock, the maximum ground acceleration of the soil surface has been calculated.

When determining the number of floors and the dimensions of the buildings, one must take 
into account that resonance phenomena form one of the most important hazards that must be avoided. Resonance takes place when the natural period of the soil equals the period of the foundations of the building. The dimension and the height of a building determine its structural vibration period, and this period increases in value with about $0.1 \mathrm{~s}$ for each additional level. For example, the structural vibration period for a 10 -floor building is calculated as $10^{*} 0.1 \mathrm{~s}$ $=1 \mathrm{~s}$; depending on the height of the structure, the natural period of the soil, $\mathrm{T}_{0^{\prime}}$ is calculated, according to the Earthquake Code (1998), as $\mathrm{T}_{0}$ $=0.005 \mathrm{H}^{3 / 4}$ ( $\mathrm{H}$ is the total height of building). The dominant natural period of the soil, $\mathrm{T}_{0 \mathrm{~s}}(\mathrm{~s})$, was calculated from the $V_{S}$ wave-velocity data. The natural period of the top (soil) layer indicates that the periods range between 0.06 and $0.13 \mathrm{~s}$. Only in the centre and in the NW part of the area, high values (>0.10 s) are found. Comparison of the natural soil periods of the site with those of the structures to be constructed in the field revealed that it would be appropriate to choose the areas with periods less than $0.09 \mathrm{~s}$ as suitable for settlement, since this value is considerably away from the natural period range of the structures $\left(\mathrm{To}_{\mathrm{b}}=0.2 \sim 0.8\right)$. One should note that buildings constructed in the area are 2 to 8 floors high.

\section{Geotechnical investigations}

In addition to the geophysical investigations, geotechnical investigations were carried out. They regard (1) analysis of borehole data; (2) performance of laboratory tests (Tab. 2), including (2a) unit-weight determination, (2b) sieve analyses, (2c) consistency-limit determination, $(2 \mathrm{~d})$ unconfined compressive tests, (2e) point-load tests and (2f) shear-strength tests. In addition, (3) the engineering properties of the graphitic shales were determined, and (4) the bearing capacity for foundations in sandstone, andesite and shale were estimated.

\section{Borehole data}

Within the study area, 21 boreholes (coded $\mathrm{BH}-1$ through $\mathrm{BH}-21$ ) were drilled; they reached depths between 9 and 20 m (Figs. 4 and 5). Seven boreholes revealed groundwater close to the surface (BH-1: $3.5 \mathrm{~m}$; $\mathrm{BH}-3: 2.85 \mathrm{~m}$; BH-5: 2.5 m; BH-10: 3.5 m; BH-18: 2.0 m: BH-20: $0.15 \mathrm{~m}$; BH-21: $3.5 \mathrm{~m}$ ).

The first unit encountered during drilling consisted of slopewash material (colluvium), and is a medium-dense to dense, practically cohesionless material; it has been found in all boreholes, except in BH-2, where andesite outcrops that forms a bearing layer of 6.0 $\mathrm{m}$ thick. The thickness of the slopewash layer ranges from $1.5 \mathrm{~m}$ to $7.0 \mathrm{~m}$. This slopewash is built of material derived from the Bornova Flysch Formation, and consists mainly of angular blocks and gravel in a matrix of sand, silt and clay. This layer is important as it is the bearing layer for the buildings. Its strength depends on both its cohesion, $\mathrm{c}$ (which is assumed to be 0 $\mathrm{MPa}$ in the case of a matrix of sand or gravelly sand), and on the angle of internal friction, $\phi$ (which is, to be on the safe side, assumed to be $\leq 20^{\circ}$, the most suitable $\phi$-value for this kind of soils); both parameters have been used in the bearing-capacity analysis.

Table 2. Laboratory test results of weathered graphitic shales.

\begin{tabular}{|c|c|c|c|c|c|c|c|c|}
\hline $\begin{array}{l}\text { Borehole } \\
\text { number }\end{array}$ & depth [m] & $\begin{array}{c}\text { natural unit } \\
\text { weight } \\
\left(\gamma_{\mathrm{n}}\right) \\
{\left[\mathrm{kN} / \mathrm{m}^{3}\right]}\end{array}$ & $\begin{array}{l}\text { liquid limit } \\
\text { (LL) } \\
{[\%]}\end{array}$ & $\begin{array}{l}\text { plastic limit } \\
\text { (PL) } \\
{[\%]}\end{array}$ & $\begin{array}{c}\text { plasticity } \\
\text { index } \\
(\mathrm{PI}) \\
{[\%]}\end{array}$ & $\begin{array}{l}\text { cohesion } \\
\left(\mathrm{C}_{\mathrm{uu}}\right) \\
{\left[\mathrm{kN} / \mathrm{m}^{2}\right]}\end{array}$ & $\begin{array}{c}\text { internal fric- } \\
\text { tion angle } \\
\left(\varnothing_{\text {uu }}{ }^{\prime}\right) \\
{\left[{ }^{\circ}\right]}\end{array}$ & $\begin{array}{c}\text { uniaxial } \\
\text { compressive } \\
\text { strength }\left(\mathrm{q}_{\mathrm{u}}\right) \\
{\left[\mathrm{kN} / \mathrm{m}^{2}\right]}\end{array}$ \\
\hline BH-3 & $11.0-12.5$ & - & 31 & 13 & 18 & - & - & 134 \\
\hline BH-7 & $4.5-2.5$ & 16.8 & 37 & 17 & 20 & 73 & 20 & 147 \\
\hline BH-7 & $12.5-16.5$ & 17.0 & 37 & 18 & 19 & - & - & 154 \\
\hline BH-10 & $9.0-10.0$ & 17.2 & 37 & 18 & 19 & 75 & 16 & 149 \\
\hline BH-10 & $19.0-20.0$ & 17.5 & 32 & 17 & 15 & - & - & - \\
\hline BH-12 & $12.5-13.5$ & 17.6 & 33 & 13 & 20 & - & - & - \\
\hline BH-20 & $6.5-7.0$ & 17.0 & 39 & 17 & 22 & 70 & 18 & 140 \\
\hline
\end{tabular}




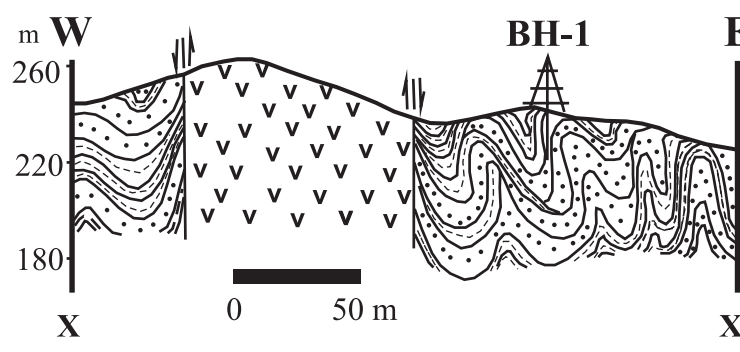

l e g e n d

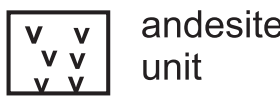

Bornova Flysch Fm.

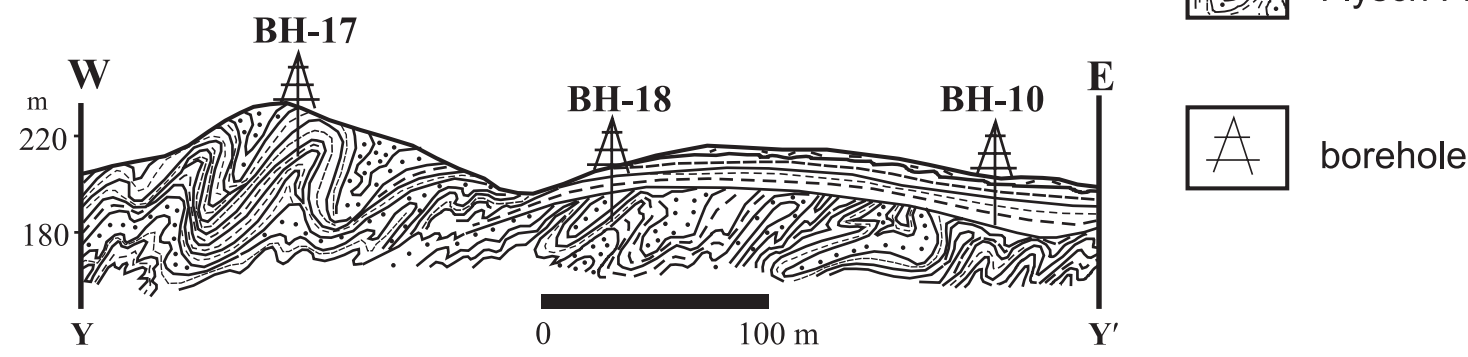

Fig. 6. Geological cross-sections (see Fig.2).

In boreholes BH-3-7, 9-15, 17, 19 and 21, the slopewash consists mainly of grey-green shale/mudstone. In BH-1, 8 and 16, it is sandstone. Disturbed samples of shale, sandstone and weathering products of the shale were collected from the borings (Fig. 6). These samples were tested in the laboratory in order to determine the index properties (Table 2). Unconfined compressive-strength tests were performed on undisturbed samples (Shelby tube samples were used for the weathered shale or soils). In addition to the laboratory results, other parameters that could be helpful for the geotechnical analysis were also obtained; these included the rock-quality designation value (RQD\%), which appeared to be $0-10 \%$, and the core-recovery value (CR\%), which appeared to range between 0 and $70 \%$.

Both the RQD\% and the CR\% values are geotechnical parameters that are used in order to clarify the fracturing of rock units in the subsurface. Core recovery $(\mathrm{CR} \%)$ is defined as the total length of core recovered from a borehole as a percentage of the length of the borehole. As simple as this approach may seem, it was found that a reasonably good relationship exists between the numerical values of the RQD and the general quality of the rock for engineering purposes. Rock-quality designation is based on a modified core-recovery procedure which, in turn, is based indirectly on the number of fractures and the degree of softening or alteration in the rock mass as observed in the rock cores from a drillhole.

Building code values are commonly used for the allowable bearing capacity of rock; however, geology, rock type, and quality (such as RQD) are significant parameters, which should be taken into account together with the recommended code value, and a safety factor that depends on RQD should be applied. The RQD\% is calculated from recovered core samples as:

$$
\mathrm{RQD} \%=\frac{\begin{array}{c}
\text { total length of intact } \\
\text { core pieces } \geq 100 \mathrm{~mm}
\end{array}}{\text { length of core advance }} \times 100
$$

One of the data that are required for the determination of the ultimate bearing capacity $\left(\mathrm{q}_{\mathrm{ult}}\right)$ of spread foundations on rock masses, as suggested by Serrano \& Olalla (1994), is the RMR value. Another parameter is the uniaxial compressive strength of the intact rock material. Bieniawski (1988) proposed a rock-mass classification, called the 'Geomechanical Classification' or the 'Rock-Mass Rating' (RMR) system. The following six parameters are used to classify a rock mass using this system: (1) $\sigma_{\mathrm{ci}^{\prime}}$ (2) RQD, (3) the spacing of the discontinuities, (4) groundwater conditions, (5) the condition of discontinuities, and (6) the orientation of discontinuities. The ratings for each of these six parameters have been established the rockmass rating system. The RMR system thus incorporates geological, geometrical and design/ 
engineering parameters in a quantitative value of the rock-mass quality.

The weakest rock unit in the area appears to be the unit of graphitic shales. This unit is found immediately under the slopewash in $\mathrm{BH}-6, \mathrm{BH}-18$ and $\mathrm{BH}-20$, whereas it is found at depths between $4.5 \mathrm{~m}$ and $13 \mathrm{~m}$ in $\mathrm{BH}-3, \mathrm{BH}-7$, $\mathrm{BH}-10, \mathrm{BH}-12, \mathrm{BH}-13$ and $\mathrm{BH}-15$ (Fig. 6). The distribution of these graphitic shales is presented in Figure 4.

\section{Laboratory tests}

In order to obtain the index and engineering properties of the exposed soil and rock types, tests to determine the unit weight (UW), the consistency limit, the uniaxial compressive strength (UCS), the point load (PL) and the shear strength (SS) tests were performed, as well as sieve analyses. Point-load tests can be performed on both core and rock pieces. In order to estimate the UCS value and the use of this parameter in the rock-mass classification instead of the UCS values, point-load tests were made. This test is also useful for determining maximum and minimum strengths that result from rock anisotropy, as in the case of laminated, folded and muddy rocks such as shales. Shales are highly fractured and have weak rock properties. A limited number of core samples suitable for UCS tests were obtained. Only eight samples were prepared from six rock samples for the UCS tests.

UCS test results were obtained from ten sandstone, ten andesite and eight shale samples. The UCS values for the sandstones ranged from 62.0 to $76.4 \mathrm{MPa}$ (the mean being $70.5 \pm 2.4 \mathrm{MPa}$ ), those for the moderately weathered andesites ranged from 38.4 to $42.5 \mathrm{MPa}$ (the average being $42.0 \pm 4.5 \mathrm{MPa}$, and those for the weathered shales ranged from 14.8 to $24.6 \mathrm{MPa}$ (the average being 20.2 $\pm 4.8 \mathrm{MPa}$ ) (Tab. 2). The sandstones, andesites and shales can therefore be classified as having, respectively, a medium, a low and a very low strength, according to the strength classification of Deere \& Miller (1966). The geomechanical test results are given in Table 2.

The strength parameters (c and $\phi$ ) along the discontinuity surfaces in the rocks are highly important because they control possible mass movements towards or even into foundation pits. These movements are controlled mainly by the friction angle $(\phi)$, cohesion (c), and direction and angle of the dip of discontinuity surfaces. The shear strength of the bedding planes of the sandstones and shales, and of the smooth-planar joints in the andesites (formed by shrinkage during cooling) were determined to analyze the stability and bearing capacity of the exposed rock units. The shear-strength test results are presented in Table 2 .

\section{Engineering properties of the graphitic shales}

The minerals in the graphitic shales were first identified by thin-section analysis. Because the particles of the shales are dominantly clay and silt-sized, it was difficult to identify all minerals by this method, so X-ray analysis has also been used to determine the composition of the shales. Minerals that were identified by X-ray analysis were found to be quartz, plagioclase, calcite, chlorite, illite, and possibly smectite (expanding clay minerals) (Fig. 7).

Grey graphitic shales that have changed by weathering into clay minerals have been encountered in the boreholes mostly under water-saturated conditions. Unit-weight determination, Atterberg consistency-limit, and direct-shear tests were performed on such samples from the boreholes. The consistency-limit tests were performed according to ASTM (1971), whereas the direct-shear tests on consolidated and drained samples were performed according to ASTM (1979b). Direct-shear tests have been performed on remoulded samples of the graphitic shale. Although a shearing rate of $0.5 \mathrm{~mm}$ per minute was fast enough to conduct UU-tests (unconsolidated-undrained), fully undrained conditions could not even be generated along the shearing surfaces of the samples of which the degree of saturation values was below $100 \%$. Therefore, direct-shear tests were performed to determine both the cohesion and the angle of shearing resistance. One might consider the values of these parameters as relevant for the stability determination as UU tests. 


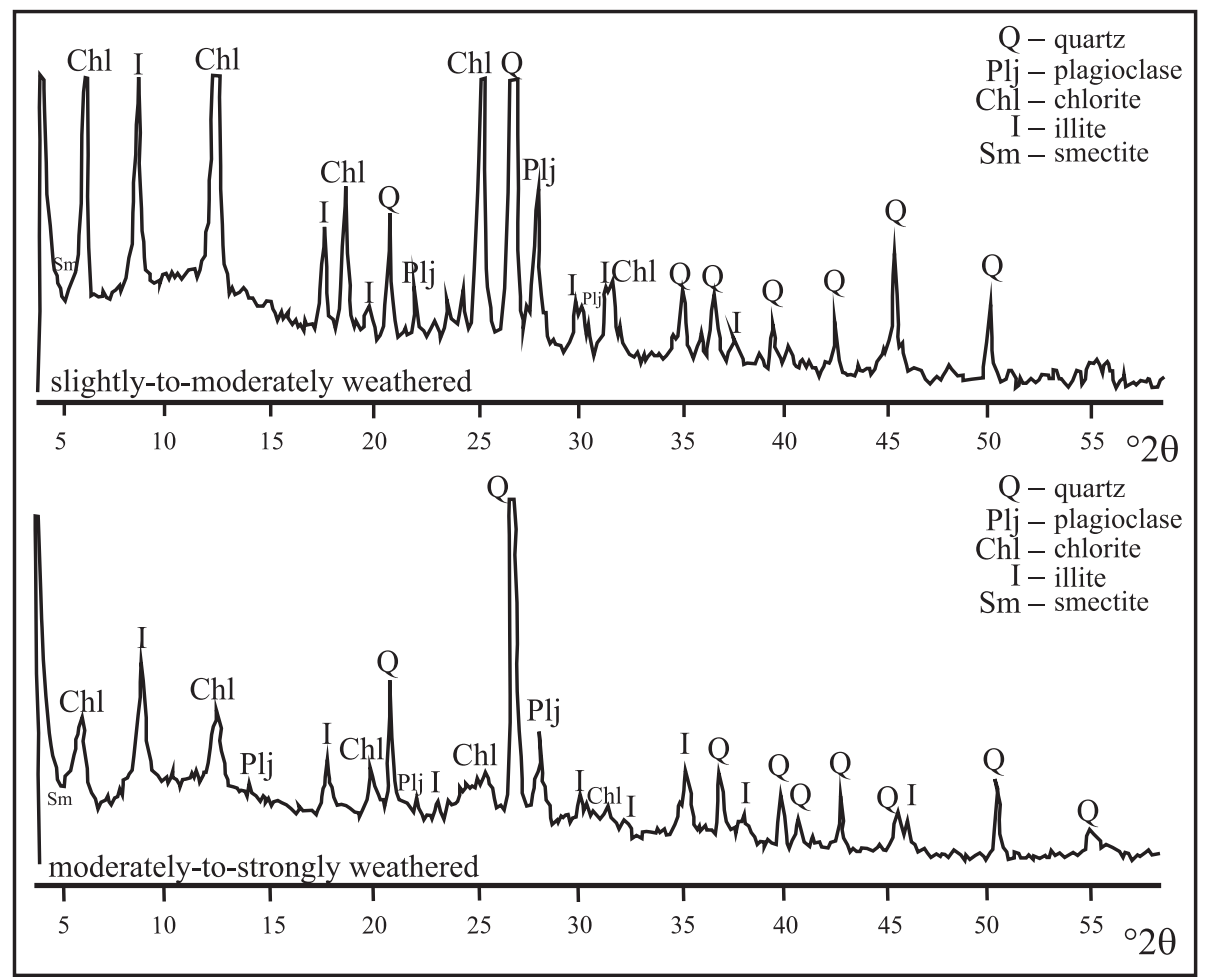

Fig. 7. X-Ray diffractogram of slightly to moderately weathered and moderately to highly weathered silty clay shale samples.
Unconfined compressive-strength tests were performed on undisturbed samples according to ASTM (1979a); the results are shown in Table 2. The UCS values of the shales vary between 134 and $154 \mathrm{kN} / \mathrm{m}^{2}$, and the graphitic shales can therefore be described as 'stiff clays'.

Inorganic clays with low to medium plasticity, being weathering products of the graphitic shales, have been found as a result of Atterberg limit tests (Tab. 2). According to the plasticityindex (PI) values, they have medium plasticity $(\mathrm{PI}=15-22 \%)$ and medium swelling potential (approx. 10-15\%). It can be deduced from the data in Table 2 that the liquid-limit and plasticlimit values of CL-type clays range between $31-39 \%$ and $13-18 \%$, respectively.

Cores that contain graphitic shales at the relatively deep level of $10 \mathrm{~m}$ have been obtained from boreholes $\mathrm{BH}-18$ and $\mathrm{BH}-20$ in the South, and from BH-6 and BH-7 in the North of the area. A depth of $10 \mathrm{~m}$ from the surface is more important than other parameters that potentially induce stress increase. Graphitic shales that are both water-saturated and deeper than $10 \mathrm{~m}$ have been encountered in boreholes $\mathrm{BH}-6, \mathrm{BH}-7, \mathrm{BH}-18$ and $\mathrm{BH}-20$. Considering the groundwater level at $2.85 \mathrm{~m}$ in $\mathrm{BH}-3$, at $3.5 \mathrm{~m}$ in $\mathrm{BH}-10$ and at $2.0 \mathrm{~m}$ in $\mathrm{BH}-18$, drainage was found to be the most important factor if multifloor buildings were considered.

\section{Estimations of the bearing capacity for foundations in sandstone, andesite and shale}

The shape factors, foundation depths and stress values for the buildings with two, four or eight floors are presented in Table 3 . The values given above were used for the computations of the bearing capacity for the foundations.

An important geological factor to be considered for any building activities is the suitability of soil and rock for bearing foundations. Data are therefore required regarding the strength

Table 3. Some selected properties of the foundations.

\begin{tabular}{lc}
\hline Depth of foundation $[\mathrm{m}]$ & 0.6 \\
Shape factor (for strip footing, $\mathrm{L} / \mathrm{B}^{*}>6$ ) & 1.0 \\
Shape factor (for square footing) & 1.25 \\
The stresses imposed by the structure & \\
to the ground $\left[\mathrm{kN} / \mathrm{m}^{2}\right]$ : & \\
For two floors & 24 \\
For four floors & 49 \\
For eight floors & 96 \\
\hline
\end{tabular}

$\mathrm{B}^{*}$ : the smallest dimension of the mat. 
Table 4. Geomechanical properties (material and mass) of exposed rock types.

\begin{tabular}{|c|c|c|c|c|c|c|c|c|c|c|}
\hline \multirow[t]{2}{*}{ Rock type } & \multirow{2}{*}{$\begin{array}{c}\text { Porosity } \\
\text { (n) } \\
{[\%]}\end{array}$} & \multirow{2}{*}{$\begin{array}{c}\text { Natu- } \\
\text { ral unit } \\
\text { weight }\left(\gamma_{\mathrm{n}}\right) \\
{\left[\mathrm{kN} / \mathrm{m}^{3}\right]}\end{array}$} & \multicolumn{2}{|c|}{$\begin{array}{l}\text { Mean internal fric- } \\
\text { tion angle }(\varphi)\left[^{\circ}\right]\end{array}$} & \multicolumn{2}{|c|}{ Cohesion $(\mathrm{c})[\mathrm{MPa}]$} & \multicolumn{2}{|c|}{$\begin{array}{c}\text { Uniaxial compres- } \\
\text { sive strength (UCS) } \\
{[\mathrm{MPa}]}\end{array}$} & \multirow{2}{*}{$\begin{array}{c}\text { Young's } \\
\text { modulus } \\
\text { [MPa] }\end{array}$} & \multirow{2}{*}{$\begin{array}{c}\text { Tensile } \\
\text { strength } \\
\text { for rock } \\
\text { mass } \\
{[\mathrm{MPa}]} \\
\text { mass }\end{array}$} \\
\hline & & & material & mass & material & mass & material & mass & & \\
\hline sandstone & $1.74 \pm 0.56$ & $25.68 \pm 0.58$ & *42 & 36.02 & 14.2 & 4.44 & $70.5 \pm 2.36$ & 17.42 & $1.49 \times 10^{4}$ & -0.210 \\
\hline andesite & $3.50 \pm 1.25$ & $23.50 \pm 0.26$ & *22 & 32.51 & 15.3 & 2.22 & $42.0 \pm 4.5$ & 8.10 & $5.62 \times 10^{3}$ & -0.029 \\
\hline shale & $5.65 \pm 2.20$ & $25.20 \pm 0.55$ & *26 & 25.77 & 13.5 & 2.06 & $20.2 \pm 4.8$ & 2.66 & $4.50 \times 10^{3}$ & -0.053 \\
\hline
\end{tabular}

* $=$ Rock-on-rock direct shear testing was performed on joints into sandstone and andesite (on cooling joints) and on bedding surfaces into the shale specimens.

and possible deformation of the soil and rock, the thickness of the soil layer, the weathering condition of the rocks, and the bearing capacities.

The geomechanical properties of the rock units in the study area have been determined on the basis of parameters such as the uniaxial compressive strength of intact rock $\left(\sigma_{\mathrm{c}}\right)$, and following a rating of the rock material according to the classification as supplied by software (RocLab, 2002; Tab. 4). The most important properties of the rock units are their tensile strength $\left(\sigma_{t m}\right)$, their modulus of deformation $\left(E_{m}\right)$, their internal friction angle $(\phi)$ and their cohesive strength (c). The $\sigma_{\mathrm{cm}^{\prime}} \sigma_{\mathrm{tm}^{\prime}} \phi$ and $\mathrm{E}_{\mathrm{m}}$ values have been obtained through calculations using the constants $\left(\mathrm{m}_{\mathrm{b}}, \mathrm{s}, \mathrm{a}\right)$ for the rock masses, and using the material constant for intact rock $\left(\mathrm{m}_{\mathrm{i}}\right)$ of the sandstone, andesite and shales; the values obtained are given in Tables 5 and 6.

Additionally, the disturbance factor (D) must be known to calculate the material con- stants ( $\mathrm{m}$ and $\mathrm{s}) . \mathrm{D}$ is a factor that depends upon the degrees of disturbance to which the rock unit has been subjected by blasting and stress relaxation. D-values vary from 0 for undisturbed in-situ rock masses to 1 for extremely disturbed rock masses.

The bearing capacity of the strip footing was evaluated from the equation $\sigma_{1}{ }^{\prime}=\mathrm{q}_{\text {ult }}=\sigma_{\mathrm{ci}}\left[\mathrm{s}^{0.5}+\right.$ $\left(m_{b} \cdot s^{0.5}+\mathrm{s}\right)^{a}$ ] (Wyllie, 1992), where $q_{u l t}$ is the ultimate bearing capacity of a rock mass. The allowable bearing capacity $\left(q_{a}\right)$ of a rock mass can be calculated from the formula (Das, 1995) $q_{a}=$ $\mathrm{q}_{\text {ult }} / \mathrm{F}(\mathrm{F}=3)$, where $F$ is the safety factor. The allowable bearing capacities $\left(q_{a}\right)$ of the rocks are presented in Tables 6 and 7. The method for determining the ultimate bearing capacity $\left(\mathrm{q}_{\mathrm{ult}}\right)$ of spread foundations on rock masses suggested by Serrano \& Olalla (1994) is based on the Hoek \& Brown rock-failure criterion and on the application of the characteristics method for resolving the differential equation systems that govern the stress field. Required data for the

Table 5. Selected $\mathrm{s}$ and $\mathrm{m}$ values for exposed jointed rock masses.

\begin{tabular}{|c|c|c|c|c|c|c|c|c|c|}
\hline \multirow{3}{*}{$\begin{array}{c}\text { Rock-mass } \\
\text { quality }\end{array}$} & \multirow{3}{*}{ Approximate joint spacing } & \multirow{3}{*}{$\begin{array}{l}\text { GSI rat- } \\
\text { ing }^{1}\end{array}$} & \multirow{3}{*}{ s-value ${ }^{2}$} & \multicolumn{6}{|c|}{$\begin{array}{c}\mathrm{m} \text {-value }{ }^{2} \text { as afunction of rock type; } \mathrm{mb}, \mathrm{mi} \text { are for broken } \\
\text { and intact rock, respectively }\end{array}$} \\
\hline & & & & \multicolumn{2}{|c|}{ shale } & \multicolumn{2}{|c|}{ sandstone } & \multicolumn{2}{|c|}{ andesite } \\
\hline & & & & $\mathrm{mi}$ & $\mathrm{mb}$ & $\mathrm{mi}$ & $\mathrm{mb}$ & $\mathrm{mi}$ & $\mathrm{mb}$ \\
\hline excellent & $>3.0 \mathrm{~m}$ (intact rock) & 100 & 1.0 & - & - & - & - & - & - \\
\hline very good & 1.0-3.0 m (interlocking) & 85 & 0.1 & - & - & 19.0 & 11.12 & - & - \\
\hline good & $1.0-3.0 \mathrm{~m}\left(\mathrm{SW} \operatorname{rock}^{3}\right)$ & 65 & 0.004 & - & - & 17.0 & 3.211 & - & - \\
\hline fair & 0.3-1.0 m (MW rock $\left.{ }^{3}\right)$ & 44 & 0.0001 & 8.0 & 0.939 & - & - & 25.0 & 2.10 \\
\hline
\end{tabular}

${ }^{1}$ Geological Strength Index (Hoek \& Bray, 1997).

${ }^{2}$ Rock-mass strength constants.

${ }^{3} \mathrm{SW}=$ slightly weathered; $\mathrm{MW}=$ moderately weathered.

Disturbance factor for sandstone: 0.50 , for andesite 0.50 , for shale 0.70 . 
Table 6. Bearing-capacity values (analyses according to Serrano \& Olalla, 1994).

\begin{tabular}{|c|c|c|c|c|}
\hline \multicolumn{5}{|c|}{ sandstone } \\
\hline RMR & $\mathrm{E}_{\mathrm{m}}[\mathrm{GPa}]$ & $\mathrm{m}_{\mathrm{i}}$ & {$\left[\mathrm{kN} / \mathrm{m}^{3}\right]$} & $\sigma_{\mathrm{ci}}[\mathrm{MPa}]$ \\
\hline \multirow[t]{4}{*}{70} & 14.9 & 17 & 25.68 & 70.5 \\
\hline & $\beta$ & & & \\
\hline & $\mathrm{z}$ & & & \\
\hline & $\mathrm{N}_{\beta}$ & & & \\
\hline \multicolumn{3}{|c|}{$\begin{array}{l}\text { ultimate bearing capacity }\left(\mathrm{q}_{\mathrm{ult}}\right) \\
{[\mathrm{MPa}]}\end{array}$} & \multicolumn{2}{|c|}{102.07} \\
\hline \multicolumn{3}{|c|}{$\mathrm{q}_{\mathrm{a}}=\mathrm{q}_{\mathrm{ult}} / 3[\mathrm{MPa}]$} & \multicolumn{2}{|c|}{34} \\
\hline \multicolumn{5}{|c|}{ andesite } \\
\hline RMR & $\mathrm{E}_{\mathrm{m}}[\mathrm{GPa}]$ & $\mathrm{m}_{\mathrm{i}}$ & $\begin{array}{c}\gamma_{\mathrm{n}} \\
{\left[\mathrm{kN} / \mathrm{m}^{3}\right]}\end{array}$ & $\sigma_{\mathrm{ci}}[\mathrm{MPa}]$ \\
\hline \multirow[t]{5}{*}{60} & 5.62 & 25 & 23.50 & 42.0 \\
\hline & $\beta$ & & & \\
\hline & $\mathrm{z}$ & & & 93 \\
\hline & $\mathrm{N}_{\beta}$ & & & \\
\hline & $\begin{array}{l}\mathrm{q}_{\mathrm{ult}}[\mathrm{MPa}] \\
\mathrm{q}_{\mathrm{ult}}=\beta(\mathrm{N} \beta-\zeta\end{array}$ & & & \\
\hline \multicolumn{3}{|c|}{$\begin{array}{l}\text { allowable bearing capacity }\left(\mathrm{q}_{\mathrm{a}}\right) \\
{[\mathrm{MPa}]}\end{array}$} & \multicolumn{2}{|c|}{11.82} \\
\hline \multicolumn{5}{|c|}{ shale } \\
\hline RMR & $\mathrm{E}_{\mathrm{m}}[\mathrm{GPa}]$ & $\mathrm{m}_{\mathrm{i}}$ & $\begin{array}{c}\gamma_{\mathrm{n}}[\mathrm{kN} / \\
\left.\mathrm{m}^{3}\right]\end{array}$ & $\sigma_{\mathrm{ci}}[\mathrm{MPa}]$ \\
\hline \multirow[t]{5}{*}{55} & 4.5 & 8.0 & 25.30 & 20.2 \\
\hline & $\beta$ & & & \\
\hline & z & & & \\
\hline & $\mathrm{N}_{\beta}$ & & & 37 \\
\hline & $\mathrm{q}_{\mathrm{ult}}[\mathrm{MPa}]$ & & & \\
\hline \multicolumn{3}{|c|}{$\begin{array}{l}\text { allowable bearing capacity }\left(\mathrm{q}_{\mathrm{a}}\right) \\
{[\mathrm{MPa}]}\end{array}$} & \multicolumn{2}{|c|}{0.3756} \\
\hline
\end{tabular}

analysis according to this method are the type of rock, the uniaxial compressive strength of the intact rock and the RMR parameter according to the classification by Bieniawski (1988).

In addition to bearing-capacity considerations, the construction of buildings in the vicinity of boreholes $\mathrm{BH}-6, \mathrm{BH}-18$ and $\mathrm{BH}-20$ should be avoided, because of the shallow groundwater table and the existence of graphitic shales, just 3-4 m below the surface. An analysis of the bearing capacity for the areas in the direct vicinity of the three just-mentioned boreholes has, therefore, not been carried out.
Table 7. Bearing-capacity values (analyses according to Hoek et al., 2002).

\begin{tabular}{|c|c|c|c|c|}
\hline \multicolumn{5}{|c|}{ sandstone } \\
\hline GSI & $S$ & $\mathrm{~m}_{\mathrm{b}}$ & a & $\sigma_{\mathrm{ci}}[\mathrm{MPa}]$ \\
\hline 65 & 0.0094 & 3.211 & 0.5 & 70.5 \\
\hline \multicolumn{5}{|c|}{ ultimate bearing capacity $\left(\mathrm{q}_{\mathrm{ult}}\right)[\mathrm{MPa}]=46.76$} \\
\hline \multicolumn{5}{|c|}{ allowable bearing capacity $\left(\mathrm{q}_{\mathrm{a}}\right)[\mathrm{MPa}]=15.59$} \\
\hline \multicolumn{5}{|c|}{ andesite } \\
\hline GSI & $S$ & $\mathrm{~m}_{\mathrm{b}}$ & $\mathrm{a}$ & $\sigma_{\mathrm{ci}}[\mathrm{MPa}]$ \\
\hline 55 & 0.0025 & 2.10 & 0.5 & 42.0 \\
\hline \multicolumn{5}{|c|}{$\mathrm{q}_{\mathrm{ult}}=16.0$} \\
\hline \multicolumn{5}{|c|}{$\mathrm{q}_{\mathrm{a}}=5.33$} \\
\hline \multicolumn{5}{|c|}{ shale } \\
\hline GSI & $S$ & $\mathrm{~m}_{\mathrm{b}}$ & a & $\sigma_{\mathrm{ci}}[\mathrm{MPa}]$ \\
\hline 55 & 0.0015 & 0.939 & 0.5 & 20.2 \\
\hline \multicolumn{5}{|c|}{$\mathrm{q}_{\mathrm{ult}}=4.71$} \\
\hline \multicolumn{5}{|c|}{$q_{a}=1.57$} \\
\hline
\end{tabular}

\section{Assessment of the ground deformations in the terrain}

The steepness of the terrain (more than $45 \%$ of the area is steeper than $20^{\circ}$ ) was considered during the preparation of the land suitability map beforehand (Fig. 8). It was also considered that the steep slopes might pose problems due to insufficiently controlled water run-off and erosion. When the ground of the area was prepared, the geological properties of shale and morphological structure of the area were taken into consideration.

Slope sliding and ground settlement are types of ground deformations that are not significant in the area since the completion of the construction of the buildings. Only at a the location $13.5 \mathrm{~m}$ away from the valley slope of the Arap Stream, some local sliding occurred during the excavation of a foundation pit. Sliding had occurred earlier along a shale bedding with a $42^{\circ}$ dip angle into the foundation pit. Other deformations took place due to differential settling: as the building was built on insufficiently compacted filled ground. The benches make up the overall slope in shales because there is commonly no stability problem for the following reasons: (1) the slope height of the benches is less than $4 \mathrm{~m}$, and (2) the geometrical condi- 
Fig. 8. Overlaid map of geology and slope (Kincal et al., 2009).

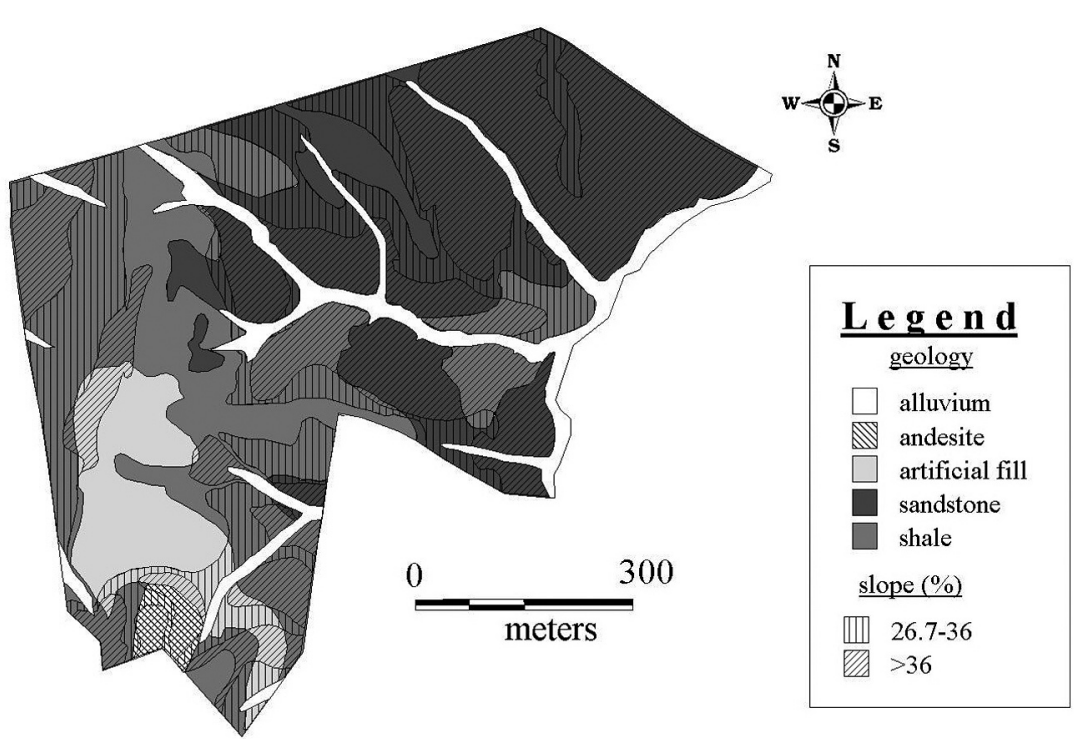

tions related with sliding along the slope are not met because $a_{\text {slope }}<a_{\text {bedding plane }}$.

Excavations with height differences of $>5 \mathrm{~m}$ in shales that formed benches with steep slopes $\left(a>60^{\circ}\right.$ ) have, however, created some stability problems because of their deterioration when exposed to air in excavations (Koca \& Kincal, 2004). One of the most important factors affecting the slope stability of the shales was exposure to alternating wetting/drying conditions of the material.

\section{Conclusions}

It appears, on the basis of the various investigations and tests carried out in both the field and the laboratory, that the graphitic shales must, if under water-saturated conditions, be considered as the weakest levels with respect to the bearing capacity. It was consequently necessary to drain the levels with these shales. The graphitic shales with medium-plasticity $(L L \%=31-39 ;$ PI\% $=13-18)$ and with the consistency of stiff clay have an unconfined compressive strength between 134 and $154 \mathrm{kN} / \mathrm{m}^{2}$. The minerals in these shales were identified by $\mathrm{X}$-ray analysis as quartz, plagioclase, calcite, chlorite, illite and smectite.

The Geological Strength Index (GSI) of the sandstones ranges between 65 and 85, and these rocks can thus be classified as 'good to very good'. The andesites and the slightly to moderately weathered shales are classified as rocks of 'fair' quality. The allowable bearing capacities of the sandstones, andesites and shales are calculated as $46.76 \mathrm{MPa}, 5.33 \mathrm{MPa}$ and 2.12 $\mathrm{MPa}$, respectively. If the foundations of buildings would reach a level with graphitic shales, it should therefore be investigated if groundimprovement techniques must be applied.

It was concluded that deep drainage must be applied to the foundations of constructions that were to be built on water-saturated graphitic shales because of the low bearing capacity of these rocks $\left(q_{u}=134-212 \mathrm{kN} / \mathrm{m}^{2}\right)$. Considering the groundwater level at $2.85 \mathrm{~m}$ in $\mathrm{BH}-3$, at $3.5 \mathrm{~m}$ in $\mathrm{BH}-10$ and at $2.0 \mathrm{~m}$ in $\mathrm{BH}-18$, drainage was found to be the most important factor if multi-floor buildings were considered.

The second-choice zones (Kincal et al., 2009) were upgraded to suitable zones by soil-improvement and reinforcement techniques that sufficiently increased both the bearing capacity of the zones and the stability of steep slopes. Soil-improvement techniques were also applied in the zones with a bearing-capacity problem in the levels with graphitic shale. Uniaxial and biaxial geogrids were applied for this improvement, in order to increase the bearing capacity of weak soils. Such soils typically are finegrained, showing a low shear strength, and they have commonly a low bearing capacity. The geogrids were placed over CL type of soils that had formed by weathering of the graphitic shales. This process was followed by control- 
led filling with crushed stone, which together with the geogrid formed a composite geogrid.

\section{Acknowledgements}

The work could not have been carried out without the close cooperation of the geological, geophysical and civil engineering departments of the Dokuz Eylul and Ege Universities. The research was supported by the Engineering Faculty of the Dokuz Eylul University (Project No. DEU-JAG-20014). Critical reviews by P. Dobak, anonymous reviewer and editor $\mathrm{T}$. Zieliński are gratefully acknowledged.

\section{Appendix: list of parameters, symbols and units}

\begin{tabular}{|c|c|c|}
\hline $\begin{array}{l}\text { symbol / } \\
\text { abbreviation }\end{array}$ & meaning & unit \\
\hline A & site-amplification & $68 \cdot V_{s}^{-0.6}$ \\
\hline $\mathrm{a}_{\max }$ & maximum ground acceleration $\left(\mathrm{a}_{\max }\right)$ & $\mathrm{m} / \mathrm{s}^{\mathrm{s}}$ \\
\hline$c^{\max }$ & cohesion & $\mathrm{MPa}$ \\
\hline $\mathrm{C}_{\mathrm{uu}}$ & cohesion (undrained and unconsolidated) & $\mathrm{MPa}$ \\
\hline cL & clay with low plasticity & - \\
\hline CR & core recovery & $\%$ \\
\hline $\mathrm{D}$ & disturbance factor & - \\
\hline $\mathrm{E}_{\mathrm{m}}$ & modulus of deformation & $\mathrm{MPa}, \mathrm{GPa}$ \\
\hline $\mathrm{F}^{\mathrm{m}}$ & safety factor & $\mathrm{F}=\mathrm{q}_{\mathrm{ult}} / \mathrm{q}_{\mathrm{a}}$ \\
\hline$\gamma_{n}$ & natural unit weight & $\mathrm{kN} / \mathrm{m}^{3}$ \\
\hline GSI & geological strength index & - \\
\hline GWL & groundwater level & $\mathrm{m}$ \\
\hline $\mathrm{H}$ & thickness of a layer & $\mathrm{m}$ \\
\hline $\mathrm{Is}_{50}$ & corrected point-load strength value & $\mathrm{kPa}, \mathrm{MPa}$ \\
\hline LL & liquid limit & $\%$ \\
\hline $\mathrm{m}$ and $\mathrm{s}$ & material constants ( $\mathrm{s}=1$ for intact rock) & - \\
\hline $\mathrm{mb}$ & reduced value of the material constant, mi & - \\
\hline $\mathrm{mi}$ & material constant of intact rock & - \\
\hline MW & moderately weathered & - \\
\hline$\phi$ & angle of internal friction & $\circ$ \\
\hline PL & plastic limit & $\%$ \\
\hline PI & plasticity index (LL-PL) & $\%$ \\
\hline PLT & point-load test & - \\
\hline $\mathrm{q}_{\mathrm{u}}$ & uniaxial compressive strength value of a soil sample & $\mathrm{kN} / \mathrm{m}^{2}, \mathrm{kPa}, \mathrm{MPa}$ \\
\hline $\mathrm{q}_{\mathrm{a}}$ & allowable bearing capacity of a rock mass & $\mathrm{kN} / \mathrm{m}^{2}, \mathrm{MPa}$ \\
\hline $\mathrm{q}_{\text {ult }}$ & ultimate bearing capacity & $\mathrm{kN} / \mathrm{m}^{2}, \mathrm{MPa}$ \\
\hline RMR & rock mass rating & - \\
\hline RQD & rock-quality designation & $\%$ \\
\hline$\sigma_{1}$ & major effective principle stress at failure & $\mathrm{kPa}, \mathrm{MPa}$ \\
\hline$\sigma_{\mathrm{ci}}$ & uniaxial compressive strength of intact rock material & $\mathrm{kPa}, \mathrm{MPa}$ \\
\hline$\sigma_{\mathrm{cm}}$ & uniaxial compressive strength of intact rock mass & $\mathrm{kPa}, \mathrm{MPa}$ \\
\hline$\sigma_{\mathrm{tm}}^{\mathrm{cm}}$ & tensile strength of rock mass & $\mathrm{kPa}, \mathrm{MPa}$ \\
\hline SW & slightly weathered & - \\
\hline SS & shear strength & - \\
\hline $\mathrm{s}$ and $\mathrm{a}$ & constants for the rock mass given by the following relationships & - \\
\hline $\mathrm{T}_{0}$ & natural period of the soil & $\mathrm{s}$ \\
\hline UC & unconfined compressive strength test of soil sample & $\mathrm{kPa}, \mathrm{MPa}$ \\
\hline UCS & uniaxial compressive strength of rock & $\mathrm{kPa}, \mathrm{MPa}$ \\
\hline UW & unit weight & $\mathrm{kN} / \mathrm{m}^{3}$ \\
\hline $\mathrm{v}$ & Poisson's ratio & - \\
\hline $\mathrm{V}_{\mathrm{p}}$ & P-wave velocity & $\mathrm{m} / \mathrm{s}$ \\
\hline $\mathrm{V}_{\mathrm{s}}^{\mathrm{p}}$ & S-wave velocity & $\mathrm{m} / \mathrm{s}$ \\
\hline$\omega^{s}$ & water content & $\%$ \\
\hline
\end{tabular}




\section{References}

ASTM, 1971. Standard test method for plastic limit and plasticity index of soil. ASTM Report D.424-59, 127-128.

ASTM, 1979a. Standard method of test for unconfined compressive strength of rock specimens. [In:] Annual book of A.S.T.M. standards19 (1980), 440-443.

ASTM, 1979b. Standard method of test for direct shear test on soils under consolidated drained conditions. [In:] Annual book of A.S.T.M. standards, D.3080-72, 487-497.

Bell, F.G., 1992. Engineering in rock masses. ButterworthHeinemann Ltd., London, 570 pp.

Bieniawski, Z. T., 1988. The Rock Mass Rating (RMR) System (Geomechanics Classification) in Engineering Practice. [In:] L. Kirkaldie (Ed.). Rock Classification Systems for Engineering Purposes. ASTM STP 984. Philadelphia, 17-34.

Bowles, J.E., 1988. Foundation Analysis and Design. Civil Engineering Series, 4th Edition, Singapure.

Brown, E.T. (Ed.), 1981. Rock characterization, testing and monitoring B ISRM suggested methods. International Society for Rock Mechanics Commission on Standardization of Laboratory and Field Tests / Pergamon Press, Oxford, 211 pp.

Das, B.M., 1995. Principles of foundation engineering ( $3^{r d} \mathrm{ed}$.). PWS Publishing Company, Boston, 148-149.

Deere, D.U. \& Miller, R.P., 1966. Engineering classification and index properties for intact rock. University of Illinois Techn. Rept. AFWL-TR-65-116, 299 pp.

Earthquake Code, 1998. Regulations for building structures that will be built in disaster areas, regulation code: 7269/1051 (sections 2 and 12) (in Turkish), http:// www.deprem.gov.tr/yonet.htm, Ankara, Turkey.

Hoek, E., 1994. Strength of rock and masses, ISRM News Journal, 2, 4-16.

Hoek, E., \& Brown, E.T., 1997. Practical Estimates of Rock Mass Strength. International Journal of Rock Mechanics and Mining Sciences 34, 1165-1186.

Hoek E., Carranza-Torres C.T. \& Corkum, B. 2002. HoekBrown failure criterion - 2002 edition. Proceedings of the North American Rock Mechanics Society Meeting, Toronto, Canada. 1-6.

Hoek, E., Marinos, P.G. \& Marinos, V. P., 2005. Characterisation and engineering properties of tectonically undisturbed but lithologically varied sedimentary rock masses. International Journal of Rock Mechanics and Mineral Science 42, 277-285.
ISRM, 1981. Rock characterization testing and monitoring. In: E.T. Brown (Ed.), ISRM suggested methods. Pergamon Press, Oxford, 113-116, 135-140.

Kincal, C. \& Koca, M.Y., 2009. A proposed method for drawing the great circle representing dip angle and strike changes. Environmental \& Engineering Geoscience 15, 145-165.

Kincal, C., Koca, M.Y. \& Van Loon, A.J., 2009. Large-scale land-suitability mapping in the GIS environment for the construction site of the University Olympic Village in Izmir (Turkey). Geologos 15, 189-198.

Koca, M.Y. \& Kincal, C., 2004. Abandoned stone quarries in and around the Izmir city centre and their geoenvironmental impacts - Turkey. Engineering Geology 75, 49-67.

Marinos, P. \& Hoek, E., 2001. Estimating the geotechnical properties of heterogeneous rock masses such as flysch. Bulletin Engineering Geology Environment 60, 85-92.

Midorikawa, S., 1987. Prediction of isoseismal maya in Kanto Plain due to hypothetical earthquake. Journal of Structural Dynamics 33B, 43-48.

Merifield, R.S., Lyamin, A.V., Sloan, S.W., 2006. Limit analysis solutions for the bearing capacity of rock masses using the generalized Hoek-Brown criterion. International Journal of Rock Mechanics and Mineral Science 43, 920-937.

RocLab, 2002. http:/ /www.rocscience.com/downloads/ RocLab.asp, Rocscience Downloads - RocLab.

Serrano, A. \& Olalla, C., 1994. Ultimate bearing capacity of rock masses. International Journal of Rock Mechanics and Mineral Science 31, 93-106.

Sönmez, H. \& Ulusay, R., 1999. Modifications to the geological strength index (GSI) and their applicability to stability of slopes. International Journal of Rock Mechanics and Mineral Science 36, 743-760.

Sönmez, H. \& Ulusay, R., 2002. A discussion on the HoekBrown failure criterion verified by the slope stability case studies. Yerbilimleri 26, 77-79.

Tarcan, G. \& Koca, M.Y., 2001. Hydrogeological and geotechnical assessment of the Kadifekale landslide area, Izmir, Turkey. Environmental Geology 40, 289-299.

Web_1. http://maps.google.com/

Wyllie, D.C., 1992. Foundation On Rock. E \& FN Press, New York, 333 pp.

Manuscript received 10 January 2010; revision accepted 16 March 2010. 